\title{
LASTEN KOTIHOITO JA SEN TALOUDELLINEN TUKEMINEN: KUNNALLISTEN LUOTTAMUSHENKILÖIDEN NÄKÖKULMA ${ }^{1}$
}

Katja Repo: YTT, professori, Tampereen yliopisto

Anu Kuukka: KT, tutkijatobtori, Jyväskylän yliopisto

Petteri Eerola: KT, YTM, tutkijatobtori, Tampereen yliopisto

katja.repo@tuni.fi,.anu.kunk.ka@jju.fi,petteri.eerola@tuni.fi

Janus vol. 27 (1) 2019, 55-71

\section{(J) a II U S}

VERTAISARVIOITU
KOLLEGIAL GRANSKAD
PEER-REVIEWED
www. tsv. filtunnus

Tiivistelmä

Artikkelissa kysytään, miten lasten kotihoidosta ja sen tukemisesta keskustellaan paikallisesti. Kunnat tuottavat lasten kotihoidon merkityksellistämiselle erityisen kontekstin. Kunnat vastaavat niin varhaiskasvatuspalvelujen järjestämisestä kuin lasten kotihoidon tuen rahoittamisesta kuitenkin niin, että oikeus kotihoidon tukeen syntyy palveluun kytkeytyvän oikeuden käyttämättä jättämisestä. Analyysi pohjautuu 32 kunnallisen luottamushenkilön haastatteluun. Haastattelut toteutettiin kymmenessä kunnassa keväällä 2016. Analyysi paikantaa aineistosta kehysanalyysin keinoin kaksi lasten kotihoitoa merkityksellistävää tulkintakehystä: talous-rationaalisen ja kulttuuris-normatiivisen tulkintakehyksen. Talous-rationaalisen tulkintakehyksen sisällä kotihoitoa pohditaan kustannussäästönä sekä kustannustehokkuuden ja kustannusohjauksen kysymyksinä. Kulttuuris-normatiivisessa tulkintakehyksessä kotihoito näyttäytyy arvovalintana ja elämäntapakysymyksenä.

\section{JOHDANTO}

Lasten kotihoidosta ja sen taloudellisesta tukemisesta on muodostunut suomalaisen perhe- ja lastenhoitopoliittisen keskustelun vakioaihe. Lasten kotihoidon tuella on vankat poliittiset kannattajansa kuin myös vastustajat. Järjestelmä on vakiinnuttanut asemansa myös lapsiperheiden arjessa. Lähes puolta 1-2-vuotiaista suomalaislapsista hoidetaan kotona ja vastaavasti hyvin pieni osuus lapsista ei ole lainkaan lasten kotihoidon tuen piirissä ennen kolmatta ikävuottaan (Kekkonen 2014; KELA 2016).

Kotihoidon suosiota on kutsuttu suomalaisen lastenhoitopolitiikan paradoksiksi (Haataja 2005). Vaikka kaikilla alle kouluikäisillä suomalaislapsilla on lakisääteinen oikeus varhaiskasvatukseen, niin Suomessa lapsia hoidetaan kotona muita Pohjoismaita pidempään (NOSOSCO 2015). Suomeen on muodostunut myös monia vakiintuneita tapoja puhua lasten kotihoidosta. Näissä keskusteluissa viitataan toistuvasti lapsen etuun, hyvään hoivaan ja vanhemmuuteen, valinnanvapauden tärkeyteen ja naisten syrjäytymiseen työelämästä (ks. Sipilä ym. 2010; 2012).

Keskustelu lasten kotihoidosta ja sen taloudellisesta tukemisesta saa erilaisia tulkintoja ajan, asiayhteyden ja keskustelijan vaihtuessa. Kunnat muodostavat lasten kotihoidosta käydylle keskustelulle oman erityisen kontekstinsa 
useasta syystä. Näistä keskeisin on, että lakisääteinen lastenhoito- ja varhaiskasvatuspolitiikka aktualisoituu kunnissa. Suomea on luonnehdittu kunnallisvaltiona, jossa kunnallinen itsehallinto hoitaa suurimman osa julkisesta palvelutuotannosta (Anttiroiko ym. 2007). Kunnat vastaavatkin niin varhaiskasvatuspalvelujen järjestämisestä kuin lasten kotihoidon tuen rahoittamisesta. Toinen keskeinen syy kuntakontekstin keskeisyydelle lasten kotihoidosta käydyssä keskustelussa on se, että vanhemmat tekevät lastenhoito- ja varhaiskasvatusvalintansa osana paikallista palvelu- ja etuusjärjestelmää (Hietamäki ym. 2017). Lisäksi kuntiin voi muodostua omia lastenhoito- ja varhaiskasvatuskulttuureja (Karila ym. 2017; Anttiroiko ym. 2007). Esimerkiksi joka viides suomalainen kunta kannustaa perheitä kotihoitovalintaan maksamalla kuntalaisilleen lakisääteisen lasten kotihoidon tuen kunnallisia lisäetuuksia (Lahtinen \& Selkee 2016).

Kunnalliset luottamushenkilöt, kuten kunnanvaltuustojen, kunnanhallitusten ja kunnallisten lautakuntien jäsenet, tuottavat erityisen, ja tähän asti tutkimattoman, näkökulman kotihoitokeskusteluun. Demokraattisesti valitut luottamushenkilöt joutuvat luottamustehtävissään pohtimaan lasten kotihoidon kysymyksiä osana kuntalaisten hyvinvointia, kuntien lakisääteisiä tehtäviä ja edustuksellisen demokratian käytäntöjä. Kunnallisilla luottamushenkilöillä on merkittävä rooli siinä, millaiseksi paikalliset lastenhoitokulttuurit muodostuvat ja kuinka eri kunnissa lasten kotihoitoon suhtaudutaan. Luottamushenkilöt ovat myös tärkeässä asemassa, kun kunnissa tehdään tulevaisuutta koskevia päätöksiä esimerkiksi siitä, mi- ten erilaisia lastenhoito- ja varhaiskasvatusvalintoja tuetaan.

Tässä artikkelissa tarkastellaan, miten kunnalliset luottamushenkilöt merkityksellistävät lasten kotihoitoa ja miten he arvioivat lasten kotihoidon yhteiskunnallista tukemista. Tutkimuskysymyksemme on, millaisin erilaisin tulkintakehyksin kunnalliset luottamushenkilöt lasten kotihoidosta ja sen tukemisesta puhuvat. Analyysin aineistona toimivat kymmenessä suomalaisessa kunnassa vuonna 2016 kerätyt luottamushenkilöiden $(n=32)$ haastattelut. Kehysanalyyttistä ajattelua soveltaen etsimme haastatteluaineistosta lasten kotihoitoa merkityksellistäviä yhteisesti jaettuja tulkintakehyksiä ja näihin sisältyviä merkityksenantoja. Lopuksi pohdimme, millaisia tasa-arvoseurauksia luottamushenkilöiden haastattelupuheesta paikantamillamme tulkintakehyksillä on niin sukupuolen kuin lasten ja lapsiperheiden näkökulmista.

\section{LASTEN KOTIHOITO: MONINAISTEN MERKITYSTEN MAAILMA}

Kansainvälisestä näkökulmasta ja muihin Pohjoismaihin verrattuna suomalaisen lastenhoitopolitiikan erityisyys paikantuu kotihoidon kysymyksiin (Mahon ym. 2012; Duvander \& Ellingsæter 2016). Suomi on muita Pohjoismaita vahvemmin institutionalisoinut kotihoitovalinnan niin varhaiskasvatuksen kuin työelämänkin vaihtoehtona. Suomen mallia on luonnehdittu myös familistiseksi, ja kotihoidosta on nähty muodostuneen erityisesti pienten lasten äitien valinta (Mahon 2002). On esitetty, että kotihoidon tuen järjestelmä tukee kokopäi- 
väistä kotihoivaa, ja että se ei kannusta vanhempien välisen hoivavastuun jakamiseen (Rantalaiho 2010).

Lasten kotihoidon tukemisella on Suomessa pitkä historia. Ensimmäiset ehdotukset kotihoidon tuen kaltaisen taloudellisen tuen maksamisesta äideille ajoittuvat jo 1940-luvulle (Anttonen 1999; Hiilamo \& Kangas 2009; Rantalaiho 2012). Varsinainen laki lasten kotihoidon tuesta säädettiin 1984. Tällä hetkellä lakisääteistä kotihoidon tukea maksetaan perheille, joiden alle 3-vuotias lapsi ei ole kunnan järjestämässä varhaiskasvatuksessa. Myös alle 3-vuotiaan lapsen alle kouluikäiset sisarukset voivat olla samoin ehdoin tuen piirissä. Kotihoidon tuki jakautuu kaikille saman suuruiseen hoitorahaan ja perheen kokoon sekä tuloihin sidottuun hoitolisään. Myös kunnat voivat tukea kotihoitovalintaa maksamalla omia kunnallisia lasten kotihoidon tuen lisäetuuksia ${ }^{2}$.

Kotihoidon tuki on osa kansainvälisesti erityistä mallia, jossa kunnallisten varhaiskasvatuspalvelujen ohella lasten hoitaminen kotona on laajalti yhteiskunnan tukemaa (Duvander \& Ellingsæter 2016; Repo ym. 2010). Myös Suomessa kunnalliset luottamushenkilöt joutuvat pohtimaan suhdettaan kotihoitoon järjestelmässä, joka tukee samanaikaisesti sekä kotihoitoa että kodin ulkopuolista varhaiskasvatusta. Vaikka lasten kotihoidon tuen virallisena tehtävänä on ollut tarjota lapsiperheille vaihtoehto kunnan järjestämille varhaiskasvatuspalvelulle (Miettunen 2008), kuntien poliittisen päätöksenteon näkökulmasta kyse ei ole kustannuksiltaan kahdesta yhtäläisestä vaihtoehdosta. Kotihoidon kustannukset lasta kohden jäävät huomattavasti varhaiskasvatuspalvelujen järjestämistä alhaisemmiksi ${ }^{3}$. Onkin esitetty, että virallisen tavoitteen ohella lasten kotihoidon tuella on ollut kuntien näkökulmasta piilotavoitteita (Anttonen 1999; Miettunen 2008). Anttosen (1999) mukaan selkein näistä on ollut sen rooli kuntien päivähoito- ja varhaiskasvatuspalvelujen kustannusten leikkaajana. On esitetty, että 1990-luvun laman aikana, jolloin erilaiset kustannussäästöt tulivat yleisesti hyväksytyiksi, tästä piilotavoitteesta tuli pikemminkin ilmitavoite (emt.).

Suomessa kunnat vastaavat sekä varhaiskasvatuspalvelujen järjestämisestä että lasten kotihoidon tuen rahoittamisesta. Varhaiskasvatuslain (19.1.1973/36, 11 momentti) mukaan "kunnan on huolehdittava siitä, että lasten päivähoitoa on saatavissa kunnan järjestämänä tai valvomana siinä laajuudessa ja sellaisin toimintamuodoin kuin kunnassa esiintyvä tarve edellyttää”. Toisin sanoen varhaiskasvatuspalvelujen osalta valtio päättää tehtävistä ja kunta hoitaa toteutuksen (ks. Anttiroiko ym. 2007). Kunnallisen päätöksenteon kannalta tärkeää on, että lainsäädäntö näkee samaan aikaan lasten kotihoidon tuen kunnallisen varhaiskasvatuspalvelun vaihtoehtona. Laki lasten kotihoidon ja yksityisen hoidon tuesta (20.12.1996/1128) esittää, että "kotihoidon tuen ja yksityisen hoidon tuen saamisen edellytyksenä on, että lapsen vanhemmat tai muut huoltajat eivät valitse lapselle kunnan järjestämää varhaiskasvatuspaikkaa”. Oikeus kotihoidon tukeen syntyy siis varhaiskasvatuspalveluihin kytkeytyvän oikeuden käyttämättä jättämisestä. 
Kunnat joutuvat siis suunnittelemaan lastenhoito- ja varhaiskasvatuskäytäntöjä kaksijakoisen lainsäädännöllisen mallin sisällä. Malli tukee kotihoitoa varhaiskasvatuspalvelujen vaihtoehtona. Kyseinen malli on ollut myös kasvavan julkisen kritiikin kohteena. Aiemman tutkimuksen pohjalta voidaan olettaa, että kunnalliset luottamushenkilöt tiedostavat yhtäältä keskustelun varhaiskasvatuksesta tärkeänä yhteiskunnallisena investointina ja toisaalta kasvavan kritiikin lasten kotihoidon tukea kohtaan (Karila ym. 2017; Sipilä 2012). Myös kuntien toimintatavat ovat erilaisia. Kotihoitoa tuetaan toisissa kunnissa rahallisesti enemmän kuin toisissa (Lahtinen \& Selkee 2016). Kunnallisista painotuksista huolimatta luottamushenkilöiden haastattelupuheesta on paikannettavissa kulttuurisesti jaettuja lasten kotihoidon merkityksellistämisen tapoja, joita tässä artikkelissa tarkastelemme.

\section{Tutkimusasetelma}

Artikkelissa kuvaamamme analyysi pohjautuu 32 kunnallisen luottamushenkilön haastatteluun, jotka toteutettiin kymmenessä kunnassa keväällä 2016 osana tasa-arvon kysymyksiä varhaiskasvatuksen, esiopetuksen ja lastenhoidon tukien järjestelmässä tarkastelevaa CHILDCARE-tutkimushanketta. Kuutta eri poliittista puoluetta edustavat luottamushenkilöt olivat joko lastenhoitokysymyksistä ja varhaiskasvatuksesta vastaavan lautakunnan, kunnanvaltuuston tai -hallituksen jäseniä. Kunnat, joita haastateltavat edustivat, sijaitsivat ympäri Suomea painottuen kuitenkin eteläiseen Suomeen. Kunnat poikkesivat toisistaan sekä useiden demografisten mittareiden, kuten väestömäärän ja -rakenteen, että taloudellisen tilanteen, työttömyysasteen ja elinkeinorakenteen suhteen ${ }^{4}$. Kunnat olivat tehneet myös erilaisia ratkaisuja kotihoidon kunnallisen tukemisen ja varhaiskasvatuksen palvelurakenteen suhteen. Näin ollen mukana olleiden kuntien voidaan nähdä edustavan kattavasti Suomen erilaisia kuntaympäristöjä.

Haastateltavat rekrytointiin mukaan tutkimukseen sähköpostitse lähetetyllä kutsukirjeellä. Haastateltavat olivat iältään 25-70-vuotiaita ja heistä valtaosa (27) oli suorittanut vähintään opistotai alemman korkeakoulututkinnon. Naisia haastateltavista oli 20 ja miehiä 12.Vapaamuotoisissa haastatteluissa keskusteltiin muun muassa haastateltavien lastenhoidon rahallisia tukia koskevista näkemyksistä ja perusteluista kunnan lastenhoidon tukien ratkaisuille. Haastattelujen keskimääräinen kesto oli noin 90 minuuttia. Haastateltavien anonymiteetin suojaamiseksi kuntaan ja haastateltavaan liittyvät tiedot on poistettu.

Tietoteoreettisilta lähtökohdiltaan artikkelimme kiinnittyy sosiaalisen konstruktionismin perinteeseen, joka korostaa sosiaalisen todellisuuden kielellistä rakentumista sekä sen kulttuurista ja historiallista luonnetta (Burr 1995). Kieli toimii tärkeänä todellisuutta tuottavana, merkityksellistävänä ja jäsentävänä toimintana (Peräkylä 1990). Metodologisesti artikkelissa hyödynnetään kehysanalyyttista ajattelua (Goffman 1974), jossa tilanteiden tulkinnan nähdään tapahtuvan erilaisten kehysten kautta. Tässä artikkelissa kutsumme tällaisia kehyksiä tulkin- 
takehyksiksi. Haastatteluaineistomme analyysissä tarkastelemme sitä, millaisin erilaisin tulkintakehyksin kunnalliset luottamushenkilöt lasten kotihoidosta ja sen tukemisesta puhuvat. Yhtäältä tulkintakehykset viittaavat yhtenäisiin tapoihin merkityksellistää ja jäsentää maailmaa. Toisaalta tulkintakehykset eivät ole kuitenkaan yksiselitteisiä ja pysyviä, vaan ne voivat niveltyä toisiinsa, olla päällekkäisiä ja vaihtua nopeasti (Alasuutari 2012; Peräkylä 1990). Tulkintakehyksiä jäsentää myös joukko sanastoltaan ja tavoitteiltaan eriytyneempiä ja yksityiskohtaisempia puhetapoja. Tässä tutkimuksessa puhetavat kuvaavat tulkintakehysten sisäistä variaatiota.

Kuvaamamme analyysi perustuu aineistolähtöiseen luentaan, jossa keskitymme mahdollisten kuntakohtaisten erojen sijaan laajempiin kunnallisten luottamushenkilöiden jakamiin tulkintakehyksiin. Paikansimme ensin haastatteluaineistosta analyysimme kohteeksi haastatteluotteita, joissa puhutaan lasten kotihoidosta ja sen tukemisesta. Tätä seuranneessa aineiston luennassa analyysiyksikkönä olivat ajatus- ja lausekokonaisuudet, jotka kommentoivat lasten kotihoitoa ja lasten kotihoidon tukemista. Erittelemämme toistuvat merkityksenannot, kuten puhe säästöistä, kustannustehokkuudesta, lapsen edusta ja hyvästä hoivasta, ryhmittelimme puolestamme yhtäältä rahaan, talouteen ja kustannuksiin sekä toisaalta perheeseen ja hoivaan liittyviksi laajemmiksi tulkintakehyksiksi. Olemme kiinnittäneet analyysissä erityistä huomiota puheen säännönmukaisuuteen sekä siihen, mihin ja millaisiin perusteluihin haastateltavat puhuessaan vetoavat ja tukeutuvat.

\section{KOTIHOIDON KUNNALLISET TULKINTAKEHYKSET}

Olemme analyysissamme paikantaneet kunnallisten luottamushenkilöiden haastattelupuheesta kaksi tulkintakehystä, joiden kautta lasten kotihoidosta ja sen tukemisesta puhutaan. Olemme nimenneet ne talous-rationaaliseksi ja kulttuuris-normatiiviseksi tulkintakehykseksi. Tulkintakehykset muodostavat ajatuksellisen ja ideologisen kokonaisuuden. Ne eivät ole kuitenkaan toisistaan irrallisia. Puhetilanteissa ne asettuvat usein dialogiseen suhteeseen kommentoiden ja perustellen toinen toistaan tai vertautuen toinen toisiinsa. Tällöin taloudelliset seikat tulevat perustelluiksi inhimillisillä tekijöillä ja kulttuuriset näkökulmat saavat tukea taloudellisista huomioista.

\section{Talous-rationaalinen tulkintakehys}

Taloudellisia seikkoja ja rationaalista talousajattelua painottavalla puheella on vahva asema kunnallisten luottamushenkilöiden lasten kotihoitoa arvottavassa ja kommentoivassa haastatteluaineistossa. Talous-rationaalisessa tulkintakehyksessä kotihoito asetetaan kunta- ja perhetalouden kontekstiin ja samalla finanssi- ja talouselämästä tuttu käsitteistö liukuu osaksi lastenhoitoratkaisujen perusteluja (ks. Kananen \& Kantola 2009; Kantola 2002). Talousrationaalisen tulkintakehyksen sisällä pohditaan kustannussäästöjä ja kustannustehokkuuden kysymyksiä. Tulkintakehys sisältää myös oletuksen siitä, että kannatettavaa ja toiminnan kannalta mielekästä on se, mikä on taloudellisesti järkevää. Siksi sen sanastoon kuuluvat myös kustannusohjauksen teemat tai "taloudellisiksi tosiasioiksi" nimettyjen 
tekijöiden kuten työmarkkinatilanteen ja perheiden taloudellisen tilanteen huomioiminen.

Analysoimassamme aineistossa pienten lasten kotihoito merkityksellistyy kunnallisille luottamushenkilöille usein tapana säästää ja karsia kustannuksia. Tämä ei ole yllättävää, sillä myös yleisempi poliittinen keskustelu, joka korostaa kotihoidon merkitystä, näkee sen kustannuksia säästävänä arvovalintana (ks. Sipilä ym. 2012). Kiristyvät kuntataloudet ja erilaiset säästöpaineet antavat lisäpontta kotihoitoa puolustavalle puheelle. Voidaankin esittää, että kustannussäästöjä korostavassa argumentoinnissa yhtäältä kunnan säästöpaineet ja toisaalta kotihoidon edullisuus suhteessa varhaiskasvatuspalvelujen järjestämisestä muodostuviin kustannuksiin muotoutuvat toimivaksi taloudellisrationaaliseksi kokonaisuudeksi. Kotihoidon tukeminen on kuntatalouden näkökulmasta säästökysymys, kuten seuraava haastattelusitaatti esittää:

"No just se, että loppujen lopuks [kunta] säästäis ensinnäkin enemmän sillä, että ne maksaa sen [kuntalisä], et ihmisil on varaa jäähä, et se on kuitenkin aina halvempaa ja parempaa se kotihoito."

Taloudellis-rationaalisessa kehyksessä lasten kotihoitoa perustellaan vetoamalla sen edullisuuteen, mutta, ja kuten edellinen sitaatti esittää, se mainitaan tässä yhteydessä useasti myös "parempana". Kyseisen logiikan mukaisesti investoinnit kotihoitoon ovat kuntatalouden näkökulmasta kannattavia kustannussäästöjä, mutta kuitenkin hyvässä ja oikeutetussa tarkoituksessa. Kotihoito arvotetaan varhaiskasvatuspalveluja tavoiteltavampana vaihtoehtona, ja siksi kotihoitovalintaa on tarkoituksenmukaista myös tukea.

Kustannussäästöjä painottavaa puhetta luonnehtii myös vetoaminen kustannustehokkuuteen. Kustannustehokkuuden taustalla on ajatus siitä, että mahdollisimman pienillä kuluilla tulee saada mahdollisimman paljon aikaan. Kuntatalouden kannalta tämä voi tarkoittaa, että kunnan järjestämisvastuulla olevat palvelut pyritään toteuttamaan mahdollisimman vähillä resursseilla ja löytämään palvelutarjonnan ongelmiin mahdollisimman vähäkustanteisia ratkaisuja. Tästä syystä kotihoidon tukemisella, kuten kotihoidon kuntalisillä, voidaan pyrkiä hakemaan ratkaisuja niin päivähoitopaikkapulaan kuin päivähoitotilojen ahtauteen. Perheille voidaankin suositella kotihoidon mahdollisuutta erilaisissa ongelmatilanteissa, kuten seuraavasta sitaattista ilmenee:

"Kuntalisähän otettiin käyttöön sen takia juuri, kun meillä oli tämä tilaongelma, ja että annettiin semmosta ensiapua perheille, että tämmönen vaihtoehto on. Ja kun ei ollu tiloja niin paljon käytössä kunnalla niin otettiin tämä kuntalisä."

Kuntatalouden näkökulmasta pienten lasten kotihoitoa luonnehditaan yleisesti varhaiskasvatuspalvelujen järjestämistä huokeampana vaihtoehtona ja siksi on taloudellisesti rationaalista luoda kannustimia kotihoitovalinnalle. Tämä tekee ymmärrettäväksi sen, että lasten kotihoidon tuen kuntalisistä käytettiin haastatteluissa toisinaan ilmauksia "porkkana", "lisäporkkana" ja "kynnyskysymys". Kuntalisillä nähdään olevan ohjausvaikutus kotihoidon piiriin ja toisinaan se nostetaan tekijäksi, 
jonka varaan päätös kotihoidon valitsemisesta kiteytyy (ks. myös Kosonen \& Huttunen 2018). Kunnallinen luottamushenkilö kuvaa tätä seuraavasti:

"Ja se saattaa olla äkkiä se, ihan satanen kaks tai tämmönenki saattaa olla se kynnyskysymys, että lähteekö se vanhempi sitte töihin ja vie lapsen päivähoitoon, vai oisko se, että kunta antaa tavallaan sen pienen avustuksen, että se ei käytä sitä päivähoitopaikkaa vaan hoitaa sen lapsen siellä kotona."

Kuntatalouden näkökulmasta kotihoidon tuen kuntalisien ohjausvaikutus tarkoittaa lähinnä sitä, että vaikutuksen tulee heijastua varhaiskasvatuspalveluiden kysyntään ja näkyä ennen kaikkea palvelutarpeen vähenemisenä. Käytännössä tällainen lähtökohta voi merkitä myös sitä, että jos kuntalisän maksamisella ei ole toivottua ohjausvaikutusta, tuen lakkauttamista tai maksettavan tukisumman pienentämistä on hyvin helppo perustella. Taloudellisesti kustannustehottomasta tuesta ei ole kiristyvän kuntatalouden kontekstissa kovin vaikea luopua, kuten käy ilmi seuraavasta kunnallisen luottamushenkilön haastattelusitaatista.

"Se oli hyvin ristiriitasta, vähän sillä lailla, että toisaalta se [kuntalisä] nähtiin semmosena kannustimena. Mutta sitte, siinä oli suurena syynä nää taloudelliset pakotteet, että oli annettu tiettyjä raameja ja, kun ne on kuitenkin, semmosia vapaaehtosia $[\ldots]$. Sitte toisaalta ei välttämättä nähty, että niissä oli mitään suurta, hyötyä ollu tai sillä lailla, että ne ois, esimerkiks ihan hirveästi niitä hoitopaikkoja vähentäny. Koettiin sitten loppuviimein että ne on, ne semmoset mistä voidaan luopua."
Kuntaliiton tutkimuksen mukaan kunnissa, joissa kotihoidon tuen kuntalisä on ollut käytössä ja joissa tuki on sittemmin lakkautettu, lakkauttamista on perusteltu tavallisesti kunnan säästöpaineilla ja sillä, että kuntalisän maksamisella ei ole ollut merkittävää vaikutusta perheiden valintoihin. Toisin sanoen kuntalisä ei ole saanut vanhempia jäämään kotiin hoitamaan lastaan. (Lahtinen \& Selkee 2016.) Analysoimassamme aineistossa kuntalisän lakkauttamiseen liitettiin myös uhkakuvia. Vaaraksi kuvattiin, että vanhemmat palaavatkin töihin ja säästöistä muodostuu tosiasiassa kustannuksia. Kotihoidon kunnalliseen tukemiseen liittyykin monitasoista tasapainottelua säästöjen, kustannusohjauksen ja vanhempien/äitien tosiasiallisten valintojen suhteen, kuten seuraava kunnallisen luottamushenkilön haastattelusitaatti esittää.
"Mutta, kyse [lasten kotihoidon tuen kuntalisä] on niin herkäst asiasta [...]. Ja sehän on vaikee asia sen takia, että kotihoidon tuen kuntalisästä leikkaami- nenhan ei oo säästö, koska, vaikka sieltä säästetään ni sittenhän, jos kannustin- vaikutin toimii siinä, että naiset menee töihin ja lapset laitetaan päivähoitoon ni sehän tulee meille kalliimmaks. Niin sen takia, se on, tosi vaikee keskustelu."

Toisinaan vanhempien, erityisesti äitien, työhön paluun todennäköisyyteen liitetään kunnan työmarkkinatilanne. Kotihoidosta säästämisestä huolimatta voidaan olettaa, että tarjolla olevien vapaiden työpaikkojen vähäisyys ja siten myös vanhempien työllistymisen epätodennäköisyys pitää vanhemman kotona, kuten seuraava haastattelusitaatti kuvaa: 
”Mä kyllä uskallan melkein väittää, et ei täällä oo ajateltu niin, et no otetaan se kotihoidontuki [kuntalisä] pois niin joo no sit ne lähtee töihin. Ei ku otetaan se kotihoidontuki pois, koska jostain on pakko säästää. Se ei oo se lakimääränen niin se me nyt sit otetaan, koska jos sanotaan suoraan niin eihän se vaikuttanu, vaikka sitte tietysti, se keskustelu siinä ennen ja jälkee ja muuta, et no nyt kaikki nää [määrä] kotona odottavaa lasta tulee päiväkotiin, no eihän ne tullu. No miten ne tulis, kun ei niille vanhemmille ollu niitä työpaikkoja."

Luottamushenkilöt liittävät taloudellisrationaalisen perusolettamuksen kuntatalouden lisäksi myös osaksi pienten lasten perheiden arkea ja perheiden valintoja. Toisinaan kotihoito näyttäytyy "pakottavana" tai jopa ainoana taloudellisesti järkevänä valintana perheille. Erityisen todennäköisenä kotihoito nähdään tilanteissa, joissa kunnan työmarkkinatilanne on huono ja äidillä heikko koulutustaso, kuten seuraavat katkelmat kuvaat:

”Ja kyllähän monilla voi olla sitten sekin, että ei oo työpaikkoja eikä ole oikein koulutustakaan, että työnsaanti olis ehkä haastavaa. Lastenhoito sitte kotona on semmonen luonnollinen valintaki."

"Elämä on ajanut siihen tilanteeseen, että ei oo oikein muutakaan vaihtoehtoa ku olla kotona, et ei oo kouluja saatu loppuun ja on tullu päihteitä ja, sit on syntyny niitä lapsia ja, ei oo ihan oikein varma, että jaksaako niitten kanssa ja muuta että, sillonhan se kotihoidontuki on ainut mikä pitää sen perheen hengissä, että sillon se on kyllä tietenkin jollakin tapaa pelastuskin sille perheelle mutta että onhan se toisaalta hyvin surullista, että sitten jää sinne, ettei oo tavallaan muuta vaihtoehtoa"

Kotihoidon tuki voidaankin nähdä keskeiseksi osaksi pienituloisten perheiden perustoimeentuloa. Kotihoidon tuen yhteys lapsiperheiden köyhyyteen nousee myös yleisemmässä akateemisessa ja yhteiskunnallisessa keskustelussa useasti esiin. Näkökulma on kuitenkin kriittinen. Tuen tulovähenteinen luonne ja matala taso kuin myös se, että heikommassa työmarkkina-asemassa olevat perheet suosivat pitkiä kotihoitoajaksoja tuottaa asetelman, joka nostaa jo ennestään hauraassa asemassa olevien lapsiperheiden köyhyysriskiä. (Sipilä ym. 2012.)

Arjessa kotihoidon tuella voidaan ratkaista perheiden toimeentulokysymyksiä. Luottamushenkilöiden näkökulmasta perheiden kannalta taloudellisesti rationaalista toimintaa on myös se, että kotiin lasten kanssa jää heikommin ansaitseva puoliso. Haastateltavat kuvaavat, kuinka tämän seurauksena kotiin jää pääasiassa äitejä:

"Kyl se varmaan sit enemmän niin, että se on sitte se nainen yleensä, kuitenki Suomessa naiset on edelleen matalapalkkasempia keskimäärin kun miehet, vaikka ovat korkeemmin koulutettuja. $\mathrm{Ni}$ että sit se nimenomaan se nainen jää sit kotiin sitä lasta hoitamaan"

\section{Kulttuuris-normatiivinen tulkintakehys}

Talousajattelulle monelta osin rinnakkaisessa kulttuuris-normatiivisessa tulkintakehyksessä tukeudutaan pehmeämmiksi tulkittaviin arvoihin ja kulttuurisiin jäsennyksiin. Tällöin ko- 
tihoito näyttäytyy monelta osin arvovalintana ja elämäntapakysymyksenä. Samalla kunnalliset luottamushenkilöt saattoivat kuitenkin vedota hyvinkin normatiivisiin ja ohjeellisiin käsityksiin siitä, mitä nämä arvot ja elämäntapavalinnat tarkoittavat käytännössä.

Taloudellis-rationaalisten seikkojen ohella lasten kotihoito tuli haastatteluaineistossa tulkituksi itsessään tärkeänä ja merkityksellisenä asiana: ainutlaatuisena ja rahalla mittaamattomana. Lasten kotihoidon tuen kuntalisää saatettiinkin kuvata muun muassa "pienenä kädenojennuksena" lapsiperheille eli tapana mahdollistaa kotihoito hyvänä ja arvokkaana hoitomuotona. Kotihoidon tukemisella nähtiin näin olevan laajempia pyrkimyksiä, kuten vanhemmuuden tukeminen ja vanhemman läsnäolon mahdollistaminen lapsen arjessa, kuten seuraava kunnallisen luottamushenkilön haastattelusitaatti esittää:

"Pitää edelleenkin mun mielest antaa mahdollisuus [kotihoitoon], ku kuitenkin asiantuntijoitten mukaan ois ihan hyvä, että kolmevuotias laps sais olla samojen ihmisten kanssa mahollisimman paljon"

Samalla korostetaan lapsen parasta. Erityisesti pienten, alle 3-vuotiaiden, lasten kotihoitoa pidettiin hyvänä vaihtoehtona. Ihmissuhteiden pysyvyyden lisäksi kotihoidon positiivisena puolena mainittiin kodinomaisuus ja turvallisuus, kuten seuraava aineistokatkelma kuvaa:

"Et se nimenomaan, monesti lapset on hyvin pieniä sillon, ku puhutaan vaikka alle kolmevuotiastakin ni, sen paikka ehkä ois paras olla ja turvallisin olla ko- tona [...] Kyllä se paras lapsen kasvatus lähtee sieltä kottoo, saa turvalliset alkuvuodet ainaki sieltä.”

Lastenhoidon valintoihin sisällytetään näin ajatus vanhemman kasvatusvastuusta. Siksi niitä ei lähtökohtaisesti tarkastellakaan vain taloudellisina päätöksinä. Hoiva- ja hoitovalinnat halutaan yleisemminkin tulkita moraalisesti oikeina, kulttuurisesti kunnollisina ja eettisesti hyväksyttävinä (Duncan ym. 2004; Sjöberg 2004). Salmen ym. (2009) tutkimuksessa kotona olevista kaksivuotiaiden lasten äideistä kaksi kolmesta olikin sitä mieltä, että "pienten lasten äitien kuuluu olla kotona" ja samaisista äideistä lähes puolet oli sitä mieltä, etteivät halunneet muiden hoitavan lastaan. Myös Hietamäen ym. (2017) tutkimus osoittaa, että pienten lasten äidit perustelevat kotihoitoa halullaan hoitaa itse omat lapsensa. Närvin (2017) tutkimus esittää, että kotihoito on Suomessa ihanne, johon monet pyrkivät. Tutkimuksen mukaan yhdeksän kymmenestä äidistä hoitaisi lastaan kotona vähintään kolmevuotiaaksi, jos äidin ei tarvitsisi ajatella toimeentuloa, mahdollisuuksiaan työelämässä tai muiden mielipiteitä (emt.).

Arvolähtökohtien rinnalla ja niihin kiinteästi kytkeytyen, pienten lasten kotihoito kuvautui haastatteluaineistossa myös kulttuurisesti tunnistettuna muotona organisoida arkea. Tätä kutsuttiin usein elämäntavaksi. Haastatteluissa viitattiin perheisiin, jotka haluavat hoitaa lapsensa kotona ja joille kotihoito on "peruselämäntapa". Kyse on perheiden omasta valinnasta, johon yhteiskunnan tuet vaikuttavat hyvin vähän. Elämäntapavalinta-näkökulma korostuu erityisesti, kun puhutaan mo- 
nilapsisista perheistä. Kunnalliset luottamushenkilöt kertovat, kuinka

"Mä en ymmärrä yhtään tota juttuu tota et naiset, töihin ja niin poispäin. [...]. Periaattees perhe saa ite päättää, et miten lasta hoidetaan."

"Meillä on tosiaan on niitä isoja perheitä, joissa äiti saattaa olla siis siitä, suurin piirtein ensimmäisen lapsen syntymästä viimeisen lapsen syntymään, kotona."

Kotihoito voidaan siis liittää perheiden omiin elämäntapavalintoihin. Aineistomme kuitenkin kuvaa, kuinka kyseessä on pääasiassa naisille mahdollistettu valinta tai jopa velvollisuus. Tällöin kulttuuris-normatiivinen tulkintakehys mukailee vanhemmuudesta vahvasti sukupuolittuneita kulttuurisia käsityksiä, joiden mukaan äiti on lapsen ensisijainen hoitaja (Eerola 2018). Kunnallinen luottamushenkilö kertoo, kuinka:

"Mä oon jotenki semmonen, että kuitenkin kun, nainen sen lapsen synnyttää niin on jotenkin loogisempaa ehkä, että se nainen sitä jää hoitamaan kotiin."

Vaikka pääasiassa kotihoito nähtiin naisten tehtäväksi, ajoittain kotihoidon tuen käytön sukupuolittuneisuus kirvoitti myös kriittisï arvioita. Tällöin oltiin huolestuneita äitien syrjäytymisestä työelämästä ja isien vähäisestä osallistumisesta lastenhoitoon.

"Kyllä, ja tää on mun mielestä ollu yks se, että minkä takia on aina itte suhtautunu kriittisesti siihen [kotihoito], että se voi jumittaa naiset kotiin liian pitkäks aikaa ja sitte sinne työmarkkinoille onkin vaikee pāästä enää takasin, ku on riittävän kauan poissa. Et on hyvä, että on mahollisuus hoitaa, että meillä on erilaiset hoitovapaat ja myös tietysti tää isyysvapaa siihen rinnalle, et se ei oo aina sitten nainen jonka sinne pitää jäädä. Et siinäki tarjotaan sitä vaihtoehtoo. Mut se, ettei luoda semmosta loukkua, että se hetken aikaa vaikuttaa hyvältä, ku tekee monta lasta peräkkäin ja on kotona ja saa siitä toimeentuloo, että selviää. Mut sitte, ku ne lapset kasvaa niin huomaaki yhtäkkiä että mitäs sitten nyt."

Lasten hoitaminen kotona näyttäytyy haastatteluissa äitien valintana ja äidille luontaisena tehtävänä, mutta myös äidille valittuna paikkana ja tehtävänä. Vaikka isien osuus vanhempainvapaiden käyttäjistä on kasvanut (Saarikallio-Torp \& Haataja 2016), niin edelleen käytännössä vain harva isä jää pidemmäksi aikaa kotiin hoitamaan pientä lasta. Erityisesti kotihoidon tuen kuntalisien on huomattu pidentävän äitien kotihoitojaksoja (Haataja 2016, 52; Kosonen \& Huttunen 2018).

\section{LOPUKSI}

Lasten kotihoidon tukea tarkastellessa on muistettava, että sosiaalipoliittiset järjestelmät ja etuudet ovat aina suhteessa omaan aikaansa ja ympäristöönsä. Tästä syystä niiden merkitykset muuttuvat ajan, paikan ja keskusteluyhteyden myötä. Ei olekaan yhdentekevää, tarkastellaanko lasten kotihoitoa osana valtakunnallista puoluepoliittista keskustelua vai lähestytäänkö kotihoidon kysymyksiä arkisten ja/tai paikallisten toimijoiden merkityksenannoista käsin. Puoluepoliittisessa toiminnassa lasten kotihoidon tuesta on muodostunut tär- 
keä poliittinen kompromissi, jolla sovitetaan yhteen erilaisia intressiristiriitoja (Anttonen \& Sipilä 2000). Lapsiperheille tuki on puolestaan usein toivottu, perheen ja työn yhteensovittamisen hektisten käytäntöjen vaihtoehto. Kotihoitovalinnan taustalla voikin olla kokemuksia liian kiireisestä työtahdista, omista tai puolison hankalista työajoista ja palkkatason mataluudesta (Hietamäki ym. 2017).

Kunnat muodostavat lasten kotihoidosta käydylle keskustelulle oman erityisen kontekstinsa. Vastaavathan kunnat niin lasten kotihoidon tuen kustannuksista kuin varhaiskasvatuspalvelujen järjestämisestä. Analyysimme perusteella kunnalliset luottamushenkilöt liittävät lasten kotihoitoon moninaisia taloudellisia, arvopohjaisia ja kulttuuriin liittyviä tekijöitä.Yhtäältä puheessa korostuvat taloudelliset kysymykset, kuten säästöt sekä kustannustehokkuus ja toisaalta kulttuuriset jäsennykset hyvästä hoivasta ja lasten parhaasta. Esitämmekin, että kunnalliset luottamushenkilöt merkityksellistävät kotihoitoa niin talous-rationaalisen kuin kulttuurisnormatiivisen tulkintakehysten sisällä. Tulkintakehykset eivät ole kuitenkaan irrallisia, vaan vertautuvat toinen toisiinsa. Kotihoito voidaan esittää kunnalle taloudellisesti huokeana, mutta samalla perheille merkityksellisenä lastenhoidon vaihtoehtona.

Kunnallisten luottamushenkilöiden näkökulmasta ja taloudellis-rationaalisen tulkintakehyksen sisällä lasten kotihoitoon kytkeytyvät valinnat näyttäytyvät kovin pragmaattisina ja arkisina. Kotihoitovalinnalla hoidetaan kunnan taloutta ja ratkotaan varhaiskasvatuspalvelujärjestelmän ongelmia. Lasten kotihoidon tuki ja erityisesti tähän liittyvät kuntalisät merkityksellistyvät tapana säästää kustannuksissa ja/ tai keinona reagoida palvelujärjestelmien toimimattomuuteen. Kyseinen puhetapa korostuu erityisesti kunnissa, joiden taloudellinen tilanne on haastava. Säästäminen saa näin paikallisen luonteen ja kytkeytyy kunnan kokonaistilanteeseen.

Kunnallisille luottamushenkilöille kotihoidon tukeminen näyttäytyykin monesti varhaiskasvatuspalvelujen tuottamista huokeampana vaihtoehtona. Kustannusten minimoiminen on ymmärrettävä näkökulma, sillä taiteilevathan useat kunnat taloudellisten ongelmien kanssa. Suomalaisen lastenhoito- ja varhaiskasvatuspolitiikan kaksinapaisuus tukee osaltaan kotihoitovalinnan merkityksellistämistä säästönä, kun valtinparina on varhaiskasvatuspalvelujen järjestäminen.

Kuntien kokonaistalous voidaan kuitenkin ymmärtää suoria kustannuksia monimutkaisempana pakettina. Pitkällä aikavälillä pitkien kotihoitojaksojen tukeminen voi tulla kunnille kannattamattomaksi. Taloustieteilijät puhuvatkin harvoin lasten kotihoidon tukijärjestelmien puolesta ja suosittelevat naisten työllisyyden lisäämistä, siitäkin huolimatta, että se tuottaa julkistaloudelle kustannuksia lasten varhaiskasvatuspalveluiden tukemisen muodossa. (Sipilä 2012.) Taloustieteilijät ja kasvavassa määrin myös poliittiset toimijat painottavat lyhyen aikavälin säästöjen sijaan pitkän aikavälin tulolisäyksiä ja varhaiskasvatuspalvelujen luonnetta sosiaalisena investointina. Muun $\mathrm{mu}-$ assa taloustieteen tutkijat Kosonen ja Huttunen (2018) havaitsivat tutkimuk- 
sessaan lasten kotihoidon tuen ja sen kunnallisten lisien vähentävän äitien työllisyyttä ja pidentävän lasten kotihoitojaksoja, mutta samalla myös heikentävän lasten pärjäämistä kognitiivisissa neuvolatesteissä.

Talous-rationaalisen tulkintakehyksen sisällä taloudellisesti rationaalista elämäntapaa tarjotaan myös perheille. Myös tutkimus osoittaa, että päätöksentekotilanteissa - erityisesti, kun kyse on lastenhoidon organisoimisesta tai perheen ja työn yhteensovittamista perheiden ratkaisut osat pikemminkin käytännöllisiä kuin ideologisia. (Närvi 2014.) Arkisessa elämässä perheissä reagoidaan monesti yllättäviinkin eteen tuleviin mahdollisuuksiin, vaihtoehtoihin ja esteisiin.

Pragmaattiseen, talouteen ja toimeentuloon kiinnyttävään puheeseen tulee kuitenkin suhtautua kriittisesti. Talouteen nojaava puhe on usein sokea talouden ja toimeentulon taustalla oleville eriarvoisuuden kysymyksille. Se, mikä on pragmaattisin lastenhoitovaihtoehto, ei ole välttämättä yhteiskunnallisen tasa-arvon näkökulmasta kaikkein kestävin. Kunnalliset luottamushenkilöt näkevät kotihoitovalinnan käytännöllisenä ratkaisuna erityisesti pienituloisissa perheissä ja perheissä, joissa äidin koulutustaso on matala. Kotihoitovalinnat ovat kuitenkin yhteydessä köyhyyteen. Tiedämme, että kotihoidon suosio ja lasten kotihoidon tuen reaaliarvon alentuminen liittyy kasvaneeseen köyhyysriskiin. Alle kolmevuotiaiden lasten perheissä köyhyysriski on ollut koko 2000-luvun selvästi korkeampi kuin lapsiperheissä keskimäärin. (Salmi ym. 2014.) Lapsiköyhyyden riski voi siis kasvaa, mikäli hoitotuet, jotka ovat usein pieniä tulonsiirtoja, saavat keskeisen aseman perheiden perustoimeentulona ja elämäntapana (Sipilä ym. 2012).

Kotihoitovalinta on kunnallisille luottamushenkilöille myös arvoihin ja elämäntapaan liittyvä kysymys. Kulttuurisnormatiivisen tulkintakehyksen sisällä kotihoito nähdään itsessään arvokkaana ja kannatettavana tai se liitetään osaksi perheiden elämäntapavalintoja. Samalla korostetaan lapsen parasta ja kotihoitoa hyvänä hoivan muotona. Luottamushenkilöiden näkemykset heijastelevat kotihoidon valinneiden vanhempien näkemyksiä. Lasten vanhemmat liittävät kotihoitoon monia positiivisia tekijöitä. Ehkä keskeisin näistä on perheajan lisääminen ja ajatus siitä, että lapsilla tulee olla oikeus vanhempien läsnäoloon. (Sipilä ym. 2012; Repo 2013; Närvi 2014.) Vanhemmat myös kertovat pitävänsä kotona olemisesta ja arvostavat äidin hoivaa (Hietamäki ym. 2017; Närvi 2017).

Kunnallisten luottamushenkilöiden arvoihin ja elämäntapaan kiinnittynyt tapa puhua kotihoidosta on kuitenkin kovin ehdollinen. Kotihoito nähdään pääsääntöisesti äitien toimintakenttänä ja elämäntapaakin tarjotaan erityisesti suurilapsisille perheille ja hoivakeskeisille äideille. Voimistuvasta tasa-arvokeskustelusta ja kasvavasta isän hoivan korostamisesta huolimatta hoivan kysymykset näyttävät meillä olevan edelleen sitkeästi naiskysymyksiä. Tätä kuvaa, kuinka luottamushenkilöiden puheissa äidit näyttäytyvät luontaisina hoivaajina. Isien hoiva ja hoivavastuiden jakaminen puolisoiden kesken jää marginaaliin. 
Närvi (2014) onkin kiteyttänyt, että vaikka perheiden hoivavalinnoista osataan nykyään puhua tasa-arvo huomioiden, tämä ei välttämättä tarkoita muutosta naisten ja miesten työnjaon käytänteissä. Hoivan kysymyksiin liittyy usein pohdintaa siitä, mikä nähdään luonnollisena, normaalina ja toisinaan jopa välttämättömänä (Stefansen \& Farstad 2010). Äidin hoivan ensisijaisuus asettuu monesti tällaiseen keskusteluyhteyteen. Myös äidit itse voivat perustella perhevapaiden käyttöä "hoivavastuullaan". Arjessa kotihoidon perusteluihin kuulunkin se, että äidin kuuluu olla kotona. Hoivavastuuta korostetaan kuitenkin sitä todennäköisemmin, mitä vähemmän äidillä on koulutusta ja mitä pienituloisempi perhe on. (Salmi ym. 2009; Närvi 2017.)

Lasten kotihoidon tukea onkin kritisoitu sen roolista perinteisen sukupuolten välisen työnjaon vahvistajana. Etenkin kansallisella tasolla korostettu tavoite sukupuolten/vanhempien välisestä tasa-arvosta jää usein taka-alalle kunnissa kunnallisen budjettivajeen ja menoleikkausten aikana. Samanaikaisesti naisten asema poliittisessa retoriikassa paikantuu helposti kotiin ja perheeseen (Sihto 2018; Karamessini \& Rubery 2014). Paikallinen lastenhoitopolitiikka voikin olla ristiriitainen suhteessa kansallisen tason pyrkimyksiin vanhempien välisen tasa-arvon ja työikäisen väestön työllisyyden lisäämisestä.

2000-luvun poliittisessa ja akateemisessa keskustelussa kotihoidon tukeminen ja varhaiskasvatukseen panostaminen jakavat mielipiteitä myös lasten yhteiskunnallisen aseman näkökulmasta. Tietoyhteiskunnan ja yhä nopeammin globalisoituvien markkinoiden aikakautena kansallista innovaatio- ja kilpailukykyä on alettu edistämään panostamalla inhimilliseen ja sosiaaliseen pääomaan. Yhä useammin korostetaankin laadukkaan varhaiskasvatuksen roolia pienten lasten oppimisen edellytyksien vahvistajina ja lasten yhteiskunnallisten erojen kaventajina. (EspingAndersen 2002; Karila ym. 2017; Sipilä \& Österbacka 2013; Erola ym. 2016.) Varhaiskasvatus halutaan nähdä lasten yhtäläisenä oikeutena ja etuna.

Kunnalliset luottamushenkilöt tunnistavat lasten jännitteisen aseman kotihoidon ja varhaiskasvatuksen ristiaallokossa. Tosin monissa kannanotoissa päädytään kannattamaan kotihoitoa lasten turvallisen kasvun ja kehityksen edellytyksenä. Lasten kotihoidon tuki voikin motivoida vanhempia jättämään lapsensa institutionaalisen varhaiskasvatuksen ulkopuolelle. Tutkimus osoittaa kuitenkin, että mitä vanhemmista lapsista on kyse, sitä ilmeisempää on, ettei koti yksin kykene tarjoamaan lapselle riittävän hyvää sosialisaatio- ja varhaiskasvatusympäristöä. (Sipilä ym. 2012.) Kotihoidossa ei ole myöskään kysymys vain alle 3-vuotiaiden lasten hoidosta, sillä kolmannes lapsista, joista maksetaan lasten kotihoidon tukea, ovat itse asiassa yli kolmivuotiaita (Kekkonen 2014). Kotihoidon suosiota yli 3-vuotiaden sisarusten osalta vahvistanee osin myös se, että monet kuntalisää maksavat kunnat edellyttävät, että ollakseen oikeutettu kotihoidon tuen kuntalisään, perheen kaikki alle kouluikäiset lapset tulee hoitaa koti (Lahtinen \& Selkee 2016).

Analyysimme pohjalta voi myös esittää, etteivät kunnalliset luottamushenkilöt näe perheiden lastenhoitoratkaisujen 
tapahtuvan rakenteellisessa tyhjiössä: kunnat pyrkivät ohjaamaan perheiden valintoja. Äidin vähäisen koulutuksen ja heikon työmarkkina-aseman nähdään ennustavan kotihoitovaihtoehtoa ja hoivan kysymykset palautuvat usein äidin hoivan ensisijaisuuteen. Kunnalliset luottamushenkilöt tunnistavat niin sosiaalipoliittisten kuin kulttuuristen rakenteiden potentiaalisen merkityksen perheiden arkisissa ratkaisuissa. Sillä, miten perheiden lastenhoito- ja varhaiskasvatusvalintoja tuetaan ja mitä hoivasta kulttuurisesti ajatellaan, näyttää olevan väliä. Kyse ei ole vain perheiden omista riippumattomista valinnoista. On siis tärkeä katsoa kriittisesti niitä institutionaalisia malleja, joiden sisällä kunnalliset luottamushenkilöt merkityksellistävät lasten kotihoitoa ja lapsiperheiden vanhemmat tekevät valintojaan lastenhoitoratkaisujen suhteen.

\section{VIITTEET}

1 Artikkeli on osa Strategisen tutkimuksen neuvoston Tasa-arvo ja yhteiskunta -ohjelman rahoittamaa CHILDCARE-projektia. Hankenumero 314317.

2 Kuntalisän maksaminen on vähentynyt. Kun vuonna 2014 kuntalisää maksettiin 30 prosentissa Kuntaliiton kyselyyn vastanneista kunnista, niin vuonna 2016 vastaava luku oli enää 23 prosenttia. Vuonna 2016 kuntalisän summat 0-3-vuotiaiden kohdalla vaihtelivat 72 eurosta 252 euroon. (Lahtinen \& Selkee 2016.)

3 Asiaa valottaa kuutoskaupunkien lastenhoidon tukien ja varhaiskasvatuspalvelujen kustannusrakenne. Kuutoskaupungeissa kunnallisen päiväkotihoidon vuosittainen kokonaiskustannus laskennallista lasta kohden oli vuonna 2015 keskimäärin 9 896 euroa, yksityisen hoidon tuen osalta keskimäärin 6670 euroa, mutta kotihoidon tuen kohdalta keskimäärin vain 5
027 euroa. (Ahlgren-Leinvuo 2016.) Kokonaisuutena kuntien varhaiskasvatukseen sekä Kelan maksamiin lastenhoidon tukiin yhteensä käyttämät kokonaismenot olivat vuonna 2014 noin 3,1 miljardia euroa. Tästä kunnallinen varhaiskasvatuksen osuus oli 85 prosenttia ja perheille maksettujen lastenhoidon tukien osuus 15 prosenttia. Kunnat maksoivat lakisääteisten tukien lisäksi kotihoidon tuen ja yksityisen hoidon tuen kuntalisiä 92 milj. euroa vuonna 2014. Päivähoidon kokonaiskustannukset ovat kasvaneet koko 2000-luvun ja vuosien 2010-2014 aikana niinkin paljon kuin 13 prosenttia. (Kuntatalouden ja -hallinnon neuvottelukunta 2016.)

4 Tilastokeskuksen tilastollisen kuntaryhmityksen mukaan kunnista 6 edustavat kaupunkimaisia kuntia, 2 taajaan asuttuja kuntia ja 2 maaseutumaisia kuntia. Luokitusta ei käytetty kuntien valintaperusteena.

\section{KirjallisuUs:}

Ahlgren-Leinvuo, Hanna (2016) Kuuden suurimman kaupungin lasten päivähoidon palvelut ja kustannukset vuonna 2015. Kuusikko-työryhmän julkaisusarja 6/2016. Helsinki: Kuusikko-työryhmä.

Alasuutari, Pertti (2012) Laadullinen Tutkimus 2.0. Tampere:Vastapaino.

Anttiroiko, Ari-Veikko \& Haveri, Arto \& Karhu, Veli \& Ryynänen Aimo \& Siitonen, Pentti (toim.) (2007) Kuntien toiminta, johtaminen ja hallintasuhteet. Tampere: Tampere University Press.

Anttonen, Anneli (1999) Lasten kotihoidon tuki suomalaisessa perhepolitiikassa. Helsinki: Kela.

Anttonen, Anneli \& Sipilä, Jorma (2000) Suomalaista sosiaalipolitiikkaa. Tampere: Vastapaino.

Burr,Vivian (1995) An Introduction to Social Constructionism. London: Routledge.

Duncan, Simon \& Edwards, Rosalind \& Reynolds, Tracey \& Alldred, Pam (2004) Mothers and Child Care: Policies, Values and Theories. Children and Society 18 (4), 254-265.

Duvander, Ann-Zofie \& Ellingsæter, Anne 
Lise (2016) Cash for Childcare Schemes in the Nordic Welfare States: Diverse paths, diverse outcomes. European Societies, 18 (1), 70-90.

Eerola, Petteri (2018) Tunteita herättävä lastenhoito. Teoksessa Petteri Eerola \& Henna Pirskanen (toim.) Perhe ja tunteet. Helsinki: Gaudeamus, 299-315.

Erola, Jani \& Jalonen, Sanni \& Lehti, Hannu (2016) Parental Education, Class and Income over Early Life Course and Children's Achievement. Research in Social Stratification and Mobility 44, 33-43.

Esping-Andersen, Gösta (2002) A ChildCentred Social Investment Strategy. Teoksessa Gösta Esping-Andersen, Duncan Gallie, Anton Hemerijck \& John Myles (toim.) Why We Need a New Welfare State. Oxford: Oxford University Press, 26-67.

Goffman, Erving (1986) Frame Analysis: an essay on the organization of experience. Boston (Mass.): Northeastern University Press.

Haataja, Anita (2005) Lasten hoitomuodon valintaoikeudet -mahdollisuuksia ja riskejä? Teoksessa Pentti Takala (toim.) Onko meillä malttia sijoittaa lapsiin? Helsinki: Kela, 80-108.

Haataja, Anita (2016) Pieniä ja suuria reformeja pienten lasten perheille suunnatuissa perhevapaissa ja -etuuksissa. Teoksessa Anita Haataja, Ilpo Airio, Miia Saarikallio-Torp \& Maria Valaste (toim.) Laulu 573566 perheestä: Lapsiperheet ja perhepolitiikka 2000-luvalla. Helsinki: Kela, 36-79.

Hietamäki, Johanna \& Kuusiholma, Julia \& Räikkönen, Eija \& Alasuutari, Maarit \& Lammi-

Taskula, Johanna \& Repo, Katja \& Karila, Kirsti \& Hautala, Paula \& Kuukka, Anu \&Paananen, Maiju \&Ruutiainen, Ville \& Eerola, Petteri (2017) Varhaiskasvatus- ja lastenhoitoratkaisut yksivuotiaiden lasten perheissä: CHILDCARE-kyselytutkimuksen 2016 perustulokset. Työpaperi: 2017 / 24. Helsinki: Terveyden ja hyvinvoinnin laitos.

Hiilamo, Heikki \& Kangas, Olli (2009) Trap for Women or Freedom to Choose? The Struggle over Cash for Child Care Schemes in Finland and Sweden. Journal of Social Policy 38 (3), 457-475.

Laki lasten kotihoidon ja yksityisen hoidon tuesta (20.12.1996/1128)

Karamessini, Maria \& Rubery, Jill (toim.) (2014) Women and Austerity. The Economic Crisis and the Future for Gender Equality. New York: Routledge.

Kananen, Johannes \& Kantola, Anu (2009) Kilpailukyky ja tuottavuus - Kuinka uudet käsitteet saavuttivat hallitsevan aseman hyvinvointivaltion muutoksessa. Teoksessa Johannes Kananen \& Juho Saari (toim.) Ajatuksen voima. Ideat hyvinvointivaltion uudistamisessa. Helsinki \& Jyväskylä: Minerva/Sophi 113, 119-152

Kantola, Anu (2002) Markkinakuri ja managerivalta: poliittinen hallinta Suomen 1990-luvun talouskriisissä. Helsinki: Loki-kirjat.

Karila, Kirsti \& Eerola, Petteri \& Alasuutari, Maarit \& Kuukka, Anu \& Siippainen, Anna (2017) Varhaiskasvatuksen järjestämisen puhekehykset kunnissa. Yhteiskuntapolitiikka 82 (4), 392-403.

Karila, Kirsti \& Kosonen, Tuomas \& Järvenkallas, Satu (2017) Varhaiskasvatuksen kehittämisen tiekartta vuosille 20172030, Suuntaviivat varhaiskasvatukseen osallistumisasteen nostamiseen sekä päiväkotien henkilöstön osaamisen, henkilöstörakenteen ja koulutuksen kehittämiseen. Opetus- ja kulttuuriministeriön julkaisuja 2017:30, Helsinki: Opetus- ja kulttuuriministeriö.

Kekkonen, Marjatta (2014) Perheiden lastenhoitojärjestelyt ja tyytyväisyys päivähoitopalveluihin. Teoksessa Johanna Lammi-Taskula and Sakari Karvonen (toim.) Lapsiperheiden hyvinvointi 2014. Helsinki: Terveyden ja hyvinvoinnin laitos, 258-72

KELA (2016) Kelan tilastollinen vuosikirja 2015. Suomen virallinen tilasto. Sosiaaliturva 2016. Helsinki: Kela.

Kosonen, Tuomas \& Huttunen, Kristiina (2018) Kotihoidon tuen vaikutus lapsiin. Palkansaajien tutkimuslaitoksen tutkimuksia 115. Helsinki: Palkansaajien tutkimuslaitos.

Kuntatalouden ja -hallinnon neuvottelukunta (2016) Peruspalvelujen tila - raportti 2016, osa I ja II, Valtiovarainministeriön julkaisuja 9/2016. Helsinki: Valtiovarainministeriö 
Lahtinen, Jarkko \& Selkee, Johanna (2016). Selvitys varhaiskasvatuksen hallinnosta, kuntalisistä ja niiden maksuperusteista sekä palveluseteleistä. Varhaiskasvatuskyselyraportti II: hallinto, kuntalisät, palveluseteli. Helsinki: Kuntaliitto.

Mahon, Rianne (2002) Child Care:Toward What kind of "Social Europe"? Social Politics 9 (3), 343-379.

Mahon, Rianne \& Anttonen, Anneli \& Bergqvist, Christina \& Brennan, Deborah \& Hobson, Barbara (2012) Convergent Care Regimes? Childcare arrangements in Australia, Canada, Finland and Sweden. Journal of European Social Policy 22 (4), 419-31.

Miettunen, Laura (2008) Lasten kotihoidon tuen kuntalisät osana suomalaista päivähoitojärjestelmää. Sosiaali- ja terveysturvan tutkimuksia 101. Helsinki: Kela.

NOSOSCO (2015) Social Protection in the Nordic Countries 2013/2014. Nordic Social Statistics Committee 60: 2015. Copenhagen: NOSOSCO.

Närvi, Johanna (2014) Määräaikainen työ, vakituinen vanhemmuus: Sukupuolistuneet työurat, perheellistyminen ja vanhempien hoivaratkaisu. Helsinki: Terveyden ja hyvinvoinnin laitos.

Närvi, Johanna (2017) Äitien perhevapaat ja osallistuminen työelämään. Teoksessa Minna Salmi \& Johanna Närvi (toim.) Perhevapaat, talouskriisi ja sukupuolten tasa-arvo. Raportti 4/2017. Helsinki: Terveyden ja hyvinvoinnin laitos, 64-104.

Peräkylä, Anssi (1990) Kuoleman monet kasvot: identiteettien tuottaminen kuolevan potilaan hoidossa. Tampere: Vastapaino.

Rantalaiho, Minna (2010) Rationalities of Cash-for-Childcare: The Nordic case. Teoksessa Jorma Sipilä, Katja Repo \& Tapio Rissanen (toim.) Cash-for-Childcare. The Consequences for Caring Mothers. Cheltenham: Edward Elgar, 109-142.

Rantalaiho, Minna (2012) Suomalainen lasten kotihoidon tuki pohjoismaisessa kehyksessä. Teoksessa Jorma Sipilä, Minna Rantalaiho, Katja Repo and Tapio Rissanen (toim.) Rakastettu ja vihattu lasten kotihoidon tuki. Tampere: Vastapaino, 65-110.
Repo, Katja (2013) The child in the context of home care - Finnish mothers' perceptions. Teoksessa Eriikka Oinonen \& Katja Repo (toim.) Private Troubles and Public Issues: Women, Men and Children in Families. Tampere: Tampere University Press, 195-212.

Repo, Katja \& Sipilä, Jorma \& Rissanen, Tapio \& Viitasalo, Niina (2010) The Paradox of the Cash-for-Childcare: Are there Ways to Solve the Dilemma?.Teoksessa Jorma Sipilä, Katja Repo \& Tapio Rissanen (toim.) Cash-for-Childcare: The Consequences for Caring Mothers. Cheltenham: Edward Elgar, 143-159.

Saarikallio-Torpp, Miia \& Haataja, Anita (2016) Isien vanhempainvapaiden käyttö on yleistynyt. Ketkä isistä vapaita käyttävät ja ketkä eivät? Teoksessa Anita Haataja, Ilpo. Airio, Miia Saarikallio-Torp \& Maria Valaste (toim.) Laulu 573566 perheestä: Lapsiperheet ja perhepolitiikka 2000-luvalla. Helsinki: Kela, 80-115.

Salmi, Minna \& Lammi-Taskula, Johanna \& Närvi, Johanna (2009) Perhevapaat ja työelämän tasa-arvo. Työ- ja elinkeinoministeriön julkaisuja, Työ ja yrittäjyys 24/2009. Helsinki: Työ- ja elinkeinoministeriö.

Salmi, Minna \& Lammi-Taskula, Johanna \& Sauli, Hannele (2014) Lapsiperheiden toimeentulo. Teoksessa Johanna Lammi-Taskula \& Sakari Karvonen (toim.) Lapsiperheiden hyvinvointi 2014. Helsinki: Terveyden ja hyvinvoinnin laitos, 82-104.

Sihto, Tiina (2018) Local childcare policy and the changing gender contract. International Journal of Sociology and Social Policy, 38 (1/2), 87-102.

Sipilä, Jorma (2012) Lasten kotihoidon tuki poliittisena kysymyksenä. Teoksessa Jorma Sipilä, Minna Rantalaiho, Katja Repo \& Tapio Rissanen (toim.) Rakastettu ja vihattu lasten kotihoidon tuki. Tampere: Vastapaino, 25-63.

Sipilä, Jorma \& Repo, Katja \& Rissanen, Tapio \& Viitasalo, Niina (2010) Cashfor-Childcare: Unnecessary Traditionalism or a Contemporary Necessity?. Teoksessa Jorma Sipilä, Katja Repo \& Tapio Rissanen (toim.) Cash-for-Childcare: The Consequences for Caring Mothers. Cheltenham: Edward Elgar, 21-45. 
Sipilä, Jorma \& Rantalaiho, Minna \& Repo, Katja \& Rissanen, Tapio (2012) Kotihoidon tuen merkitys ja tulevaisuus. Teoksessa Jorma Sipilä, Minna Rantalaiho, Katja Repo \& Tapio Rissanen (toim.) Rakastettu ja vihattu lasten kotihoidon tuki. Tampere:Vastapaino, 183-2015.

Sipilä, Jorma \& Österbacka, Eva (2013) Enemmän ongelmien ehkäisyä, vähemmän korjailua? Perheitä ja lapsia tukevien palvelujen tuloksellisuus ja kustannusvaikuttavuus. Valtionvarainministeriön julkaisuja. Helsinki:Valtionvarainministeriö.
Sjöberg, Ola (2004) The Role of Family Policy Institutions in Explaining Gender-Role Attitudes. A Comparative Multilevel Analysis of Thirteen Industrialized Countries. Journal of European Social Policy 14 (2), 107-123.

Stefansen, Kari \& Gunhild R. Farstad (2010) Classed Parental Practices in a Modern Welfare State. Caring for the Under Threes in Norway. Critical Social Policy 30 (1), 120-141.

Varhaiskasvatuslaki (19.1.1973/36) 